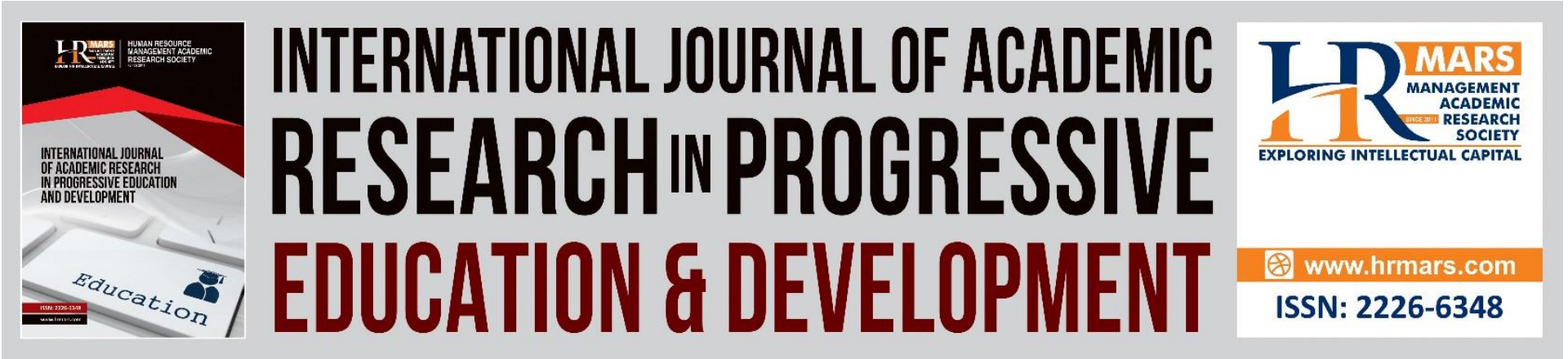

\title{
Teachers Wellbeing in Malaysia: A Review
}

\section{Zaine Zulkifli, Intan Hashimah Mohd Hashim \& Mahathir Yahaya}

To Link this Article: http://dx.doi.org/10.6007/IJARPED/v11-i1/12262

DOI:10.6007/IJARPED/v11-i1/12262

Received: 14 November 2021, Revised: 18 December 2021, Accepted: 07 January 2022

Published Online: 25 January 2022

In-Text Citation: (Zulkifli et al., 2022)

To Cite this Article: Zulkifli, Z., Hashim, I. H. M., \& Yahaya, M. (2022). Teachers Wellbeing in Malaysia: A Review. International Journal of Academic Research in Progressive Education and Development, 11(1), 703-712.

Copyright: (C) 2022 The Author(s)

Published by Human Resource Management Academic Research Society (www.hrmars.com)

This article is published under the Creative Commons Attribution (CC BY 4.0) license. Anyone may reproduce, distribute, translate and create derivative works of this article (for both commercial and non-commercial purposes), subject to full attribution to the original publication and authors. The full terms of this license may be seen

at: http://creativecommons.org/licences/by/4.0/legalcode

\section{Vol. 11(1) 2022, Pg. $703-712$}

Full Terms \& Conditions of access and use can be found at http://hrmars.com/index.php/pages/detail/publication-ethics 


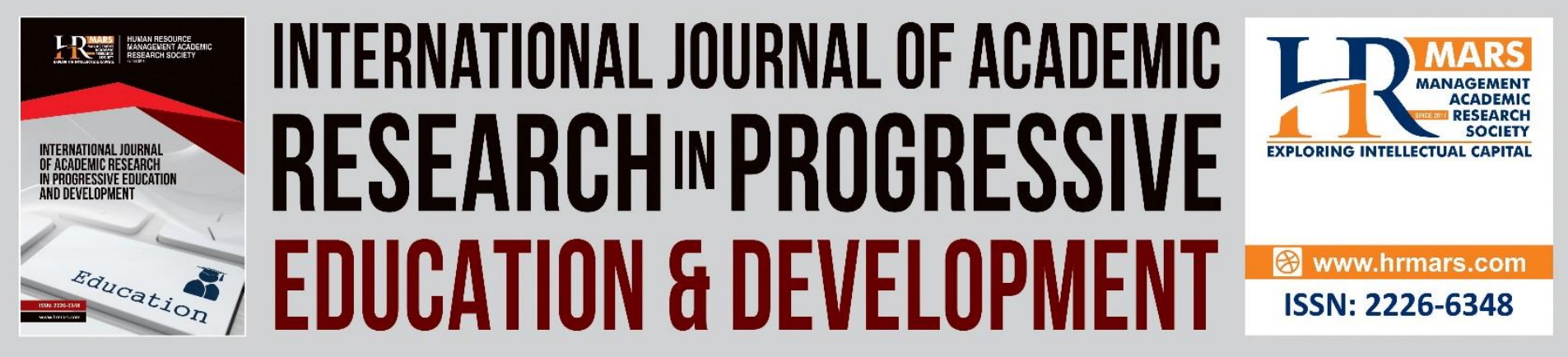

\title{
Teachers Wellbeing in Malaysia: A Review
}

\section{Zaine Zulkifli, Intan Hashimah Mohd Hashim \& Mahathir Yahaya \\ School of Social Sciences, Universiti Sains Malaysia}

\begin{abstract}
Background/purpose: The role of teachers is vital in educational institutions. They are considered the main pillar in the educational system. As Malaysia is going through educational transformations and moving towards the fourth industrial revolution, teacher wellbeing is one of the areas that needs to relook. The concept of wellbeing among teachers has been taken attention in educational institutions due to its great importance. This study aims to identify the elements associate with the wellbeing of teachers in Malaysia. Therefore, the purpose of this study was to review the previous studies on wellbeing in teaching professionals.
\end{abstract}

Methods: The studies that investigated the wellbeing of teachers in Malaysia were retrieved from Science Direct, Scopus, and Google Scholar, and selected studies were reviewed.

Implications: A career as a teacher is plagued with difficulties, such as workplace stress, anxiety, and a heavy workload, all of which interfere with one's wellbeing. Previous studies looked at a variety of factors to create strong teacher wellbeing, including job satisfaction, resilience, emotional intelligence, and so on. Exploration of additional psychological components is critical for improving teachers' wellbeing.

Conclusion: Teachers must be exposed to factors that promote wellbeing in order for classroom learning sessions to be effective. Furthermore, teachers' wellbeing has a favourable impact on the achievement of students and schools.

Keywords: Wellbeing, Health, Teachers, Malaysia

\section{Introduction}

Teachers are one of the most challenging and complex professions. The job design of a teacher is more complicated, intense, and demanding. It causes stress and puts teachers at a greater risk of leaving the profession than other jobs. Teaching has been described as one of the most stressful professions (Borman \& Dowling, 2008; Lovewell, 2012), with high rates of burnout (Durr et al., 2014; Maslach et al., 2001). Teachers, in this regard, are accountable for a broader range of more complex tasks than other occupations, not only academic-related but also burdened with clinical responsibilities and student self-management, for instance, student discipline issues. Unsurprisingly, this has also resulted in alarming attrition rates, particularly among teachers in the early stages of their careers, who are confronted with realities opposed to their expectations and hopes (Johnson et al., 2015). Thus, the task of 
teachers becomes more demanding in ensuring that the goal of developing and enhancing one's potential as a teacher is met to the fullest extent possible.

Although the variety of challenges in the profession can be viewed as a dynamic career challenge, the emotional stress experienced has an impact on wellbeing. As a result, teachers' psychological needs should be met in order for them to develop a positive identity and a high quality of life (Desa et al., 2009; McGregor et al., 2009). Individuals' mental health and wellbeing will suffer as a result of its deficiency, leading to psychological disorders (Goetzel et al., 2002). Thus, teachers must be emotionally sensitive in order for the teaching and learning process to be born from feelings (Emmer \& Stough, 2001) and have strong psychological resilience in order to face the various challenges that students have (Hong, 2012). Only individuals with solid psychological resilience can face various educational challenges and indirectly improving their wellbeing.

Bradburn (1969) emphasised how psychological wellbeing was the element that stood out as being of main importance in his classic research. His debate on wellbeing arose from his interest in how people dealt with the issues that they faced on a daily basis. The concept of wellbeing encompasses a variety of dimensions, including positive affect, negative affect, and life satisfaction. Myers and Diener (1995), proposed that wellbeing is defined as the relative presence of positive affect, the absence of negative affect, and satisfaction with life. Shin and Johnson (1978) defined wellbeing as "a universal evaluation of an individual's quality of life based on his or her own criteria," and this assessment is still represented in modern literature (Rees et al., 2010; Statham \& Chase, 2010). Ryff (1989), described wellbeing as having the following characteristics includes purpose in life, autonomy, pleasant connections, environmental mastery, and self-acceptance. Most scholars now believe that wellbeing is a multidimensional concept (Diener, 2009; Michaelson et al., 2009; Stone et al., 2018). According to Marks and Shah (2004), wellbeing is more than just happiness. Wellbeing includes not just feeling satisfied and cheerful, but also growing as a person, finding fulfilment, and contributing to the community. Flourish (Seligman, 2011) is Seligman's book in which he introduces his new dynamic concept of wellbeing, which differs from ideas focused only on happiness. His new wellbeing theory focuses on aspects of wellbeing that he describes as a set of building blocks for a flourishing life includes positive emotion, engagement, relationships, meaning, and achievement (PERMA).

While various aspects of wellbeing have been studied for over three decades, empirical research into the wellbeing of teachers is much more recent (Pavot, Diener, Oishi, \& Tay, 2018). However, research has demonstrated how critical it is for teachers to thrive in their professional roles. For instance, several studies have discovered a positive correlation between teacher wellbeing and teaching effectiveness (Day \& Qing, 2009; Gyeltshen \& Beri, 2018; Shepherd et al., 2016). Additionally, it has been shown to correlate positively with student achievement (Briner \& Dewberry, 2007; Wubbels et al., 2016) and student wellbeing (Harding et al., 2019), indicating that teacher wellbeing benefits not only teachers but also their students.

In Malaysia, research on wellbeing has been undertaken extensively in a variety of contexts, including students (Awang et al., 2014; Nordin \& Talib, 2009; Thartori \& Nordin, 2019), academicians (Bavani \& Mohan, 2015), adolescents (Naeemi, Tamam, Hassan, \& Bolong, 2014), parents (Hassan, Yusooff, \& Alavi, 2014) and the elderly (Momtaz et al. , 2011), among others. The researches in employment sector is more heavily concentrated in the field of health and medicine (Achour et al., 2019; Lan et al., 2014; Park et al., 2020; Tahir, Hussein, \& Samad, 2017; Zaki \& Halim, 2020). There are few and limited studies on teacher wellbeing. 
However, since 2019, the research of teacher wellbeing in Malaysia has risen. Researchers in Malaysia are beginning to recognise the significance of teacher wellbeing. The following section will discuss the highlights of the study of teacher wellbeing in Malaysia.

\section{Literature Review}

A study conducted by Razak and Kutty (2021) investigated the level of resilience of teachers, coping strategies, the level of psychological wellbeing and the relationship between the level of resilience and coping strategies on the level of psychological wellbeing of teachers in Kuala Pilah. This study uses a quantitative approach based on survey design. The study population consisted of primary school teachers in the Kuala Pilah district. This study used the random sampling method, and 258 teachers were involved as the study sample. The Resilience Scale, Brief COPE and Flourishing Scale (FS) were used in this study. Findings showed that teachers in Kuala Pilah had a high level of resilience. Teachers were more likely to use problem-focused coping strategies when faced with sources of stress and had a high level of psychological wellbeing. In addition, the findings showed that there was a significant relationship between the level of resilience with the level of psychological wellbeing of teachers and teachers' coping strategies. The study's findings serve as a direction for stakeholders to focus their efforts on meeting teachers' wellbeing through approaches to develop teachers' resilience. In accordance with the challenges that arise, teachers' wellbeing can be ensured if they know the appropriate coping mechanisms to employ when confronted with difficulties at the workplace (Gustems-Carnicer et al., 2019).

Leow, Lee, and Leow (2020) found a significant positive relationship between teachers' satisfaction with co-workers, students' behaviours, and teachers' mental wellbeing. The study was conducted to investigate the association between job satisfaction and wellbeing among Malaysian high school teachers. The Teacher Job Satisfaction Scale and the Short WarwickEdinburgh Mental Wellbeing Scale were completed by 111 full-time high school teachers from two schools in Kuala Lumpur, Malaysia. This study highlighted the importance of job satisfaction for teachers in maintaining positive personal relationships with co-workers, students, and parents. It contributed to a better understanding of the contribution of job satisfaction to teachers' mental wellbeing in general. Teachers are change agents, and understanding teachers' mental wellbeing may aid in the spread of intervention programmes in schools as well as reducing teacher attrition. According to the findings of this study, teachers' mental wellbeing is influenced by their satisfaction with their co-workers as well as their satisfaction with their students' behaviour and were supported by the previous findings (Simon et al., 2010; Virtanen, Vaaland, \& Ertesvåg, 2019).

Yusoff and Tengku-Ariffin (2020), conducted a study to identify whether the positive internal environment will ensure that teachers are happy and enjoy their work. The aim of their study is to investigate the relationship between teacher empowerment and teacher wellbeing in the workplace. It examines the many subscales of teacher empowerment in order to establish which subscales are the most accurate predictors of teachers' wellbeing. This study was a cross-sectional survey of 371 Malaysian school teachers chosen using multi-stage sampling in one of the country's states. The study was conducted with a quantitative approach using self-report questionnaires. The results revealed no statistically significant difference in teacher wellbeing depending on demographic parameters (gender and age). The results also revealed significant positive associations between teacher empowerment and teachers wellbeing. Only the decision-making dimension positively and significantly predicted teachers' wellbeing in a separate analysis of the teacher empowerment dimensions. As a 
detail, teachers are able to achieve their wellbeing if they get the autonomy in decision making. The higher level of teacher autonomy and power will create professional educators who are more proactive and innovative (Abdul Jalil et al., 2019; Arbaa et al., 2017).

Ngui and Lay (2019), conducted a study related to self-efficacy, emotional intelligence, and subjective wellbeing among teachers. Mediating role of resilience on these relationships were also examined. The study employs a quantitative research method in the form of a survey research design. A total of 200 questionnaires were delivered to respondents. The respondents were selected based on stratified random sampling. All questionnaires were successfully retrieved for final data analyses. The data in their study shows a significant association between self-efficacy, emotional intelligence, and subjective wellbeing. Analysis shown resilience play role in mediating this relationship. This study adds to the body of evidence demonstrating the importance of teacher self-efficacy, emotional intelligence, and resilience in the development of quality educators. It is also crucial to highlight that when teachers are able to manage and regulate their emotion efficiently, it indicates that they are in good health and wellbeing. Teachers' self-efficacy, emotional intelligence, and wellbeing are essential aspects that are linked to being more effective at their jobs. The findings of the study indicate that teachers' wellbeing is vital in order for them to excel in teaching and learning. Previous work of literature also found that teachers wellbeing play a role in teaching effectiveness in the classroom (Day \& Qing, 2009; Gyeltshen \& Beri, 2018; Shepherd et al., 2016).

Zakaria, Don, and Yaakob (2020) found that the level of teachers' wellbeing was high and that there was no difference in the level of teachers' wellbeing in secondary schools (SMK) and religious schools. The goal of this research was to look at the wellbeing of teachers in secondary schools and religious schools based on the quality of their working lives, namely psychological, social, political, and socioeconomic concerns. A descriptive survey was conducted on 300 teachers in the Pasir Puteh district of Kelantan who was selected based on a random sampling technique. The research instrument was modified from the Quality of Teachers' Working Life survey. The findings indicate that both types of schools had high mean levels, although there were disparities in results between schools. Secondary schools (SMK) had a somewhat higher mean score than religious schools. This study suggested that the secondary schools (SMK) teachers operate in a more ordered setting, and the facilities supplied were superior to those at the religious schools. Teachers and students will be more motivated if the school climate is positive, and teaching and learning activities will run smoothly (Kasim et al., 2017).

\section{Methodology}

The keywords used in the search process of previous related studies include subjective wellbeing, psychological wellbeing, mental health, and teacher. Previous studies have been obtained through an online database such as Science Direct, Scopus, and Google Scholar. The following criteria were used to search for earlier studies that are relevant:

1. Research on teachers wellbeing in Malaysia;

2. The study focuses on the educational setting;

3. Studies published between 2016 to date; and

4. The study should indicate the variable of subjective wellbeing or psychological wellbeing. 
DEVELOPMENT

Vol. 11, No. 1, 2022, E-ISSN: 2226-6348 @ 2022 HRMARS

For the selection of research publications starting from 2016 to date is to ensure that these studies are current and updated. After a qualitative analysis, a meta-analysis of wellbeing variables in the educational setting has been carried out, and a summary of the findings is provided in Table 1 for wellbeing.

Table 1: Meta-Analysis of Wellbeing

\begin{tabular}{lll}
\hline \multicolumn{2}{c}{ Elements } & Studies \\
\hline 1 & Resilience & (Ngui \& Lay, 2019; Razak \& Kutty, 2021) \\
2 & Coping Strategies & (Razak \& Kutty, 2021) \\
3 & Job Satisfaction & (Leow et al., 2020) \\
4 & Teacher Empowerment & (Yusoff \& Tengku-Ariffin, 2020) \\
5 & Self-efficacy & (Ngui \& Lay, 2019) \\
6 & Emotional Intelligence & (Ngui \& Lay, 2019) \\
7 & Type of School & (Zakaria et al., 2020)
\end{tabular}

\section{Discussion and Conclusion}

Some scholars' points of view are consistent with the demands of teachers as well as the realities of school life. According to these viewpoints, every aspect plays a critical part in improving teacher wellbeing in the classroom. Studies have emphasised the relevance of coping mechanisms, resilience, work satisfaction, teacher empowerment, self-efficacy, emotional intelligence, and school environment, among other things. Teachers' psychological wellbeing is improved as a result of these variables. The study also highlights the contribution of teacher wellbeing and its impact on teaching effectiveness. When schools place a high priority on teacher wellbeing and assist in ensuring that teachers can thrive, this may result in better classroom climates and the provision of high-quality instruction that leads to student achievement. In addition, teacher wellbeing is connected to student wellbeing, and addressing teacher wellbeing is a crucial first step in implementing school-wide wellness programmes to improve student wellbeing. As a result, it is mentioned once more that the wellbeing of teachers is highly essential to be paid attention to by specific parties since it will also affect the impact on students in school.

Teachers wellbeing is vital in ensuring that teachers are consistent in providing the best teaching and learning to their students. The role played by coping strategies, job satisfaction, school climate, professional development, and teacher empowerment are essential in improving the level of teacher wellbeing. Hence, the author proposes a study on the exploration of other factors that can influence teacher wellbeing in the Malaysian population. Furthermore, studies on this area are limited in the Malaysian context. Therefore, a deeper exploration in this area needs to be developed in order to have a significant contribution and positive impact on the wellbeing of teachers while improving the quality of education in Malaysia. 
In conclusion, this study discovered that only five studies were completed in Malaysia on factors that can increase teacher wellbeing. This is concerning because the Ministry of Education Malaysia reported that the majority of Malaysian teachers have low to medium levels of wellbeing in 2019 (Yahya, Ishak, Rahim, \& Usuldin, 2020). According to literature, many factors such as resilience, teacher empowerment, job satisfaction, self-efficacy, and emotional intelligence influence teacher wellbeing. This influence is critical in increasing teachers' overall wellbeing. However, such research are limited and should be expanded in the context of Malaysian educators. As a result, this study advises that studies on teachers' character strengths be explored in the context of Malaysian education. This can enhance not just the wellbeing of teachers, but also the performance of teachers, students, and schools.

Teacher wellbeing includes life satisfaction, quality of life, happiness, and flourishing are common factors in individual life, especially for an educator. It is crucial for a teacher to achieve good physical and psychological wellbeing in their careers to ensure that the teaching and learning sessions are progressing smoothly. Thus, this study emphasises the importance of teachers' wellbeing in Malaysia.

\section{Corresponding Author}

Zaine Zulkifli

Email: zainezulkifli92@gmail.com

\section{Acknowledgement}

School of Social Sciences, Universiti Sains Malaysia

\section{References}

Abdul Jalil, A., Abdul Ghani Kanesan, A., \& Isrihan, M. (2019). Amalan Pengupayaan Dan Autonomi Guru Dalam Pembelajaran Dan Pemudahcaraan Abad Ke 21. Jurnal Kepimpinan Pendidikan, 6(1), 49-58.

Achour, M., Azmi, I. B. A. G., Isahak, M. B., Nor, M. R. M., \& Yusoff, M. Y. Z. M. (2019). Job stress and nurses well-being: Prayer and age as moderators. Community mental health journal, 55(7), 1226-1235. doi: https://doi.org/10.1007/s10597-019-00410-y

Arbaa, R., Jamil, H., \& Ahmad, M. Z. (2017). Model Bersepadu Penerapan Kemahiran Abad Ke21 dalam Pengajaran dan Pembelajaran (Integrated Model of Infusing 21st Century Skills in Teaching and Learning). Jurnal Pendidikan Malaysia (Malaysian Journal of Education), 42(1), 1-11. doi: https://ejournal.ukm.my/jpend/article/view/19590

Awang, M. M., Kutty, F. M., \& Ahmad, A. R. (2014). Perceived Social Support and Well Being: First-Year Student Experience in University. International Education Studies, 7(13), 261270. doi: https://eric.ed.gov/?id=EJ1071180

Bavani, S., \& Mohan, R. (2015). Self-satisfaction and psychological well being of academicians at private Universities in Malaysia. International Journal of Novel Research in Education and Learning, 2(3), 60-70.

Borman, G. D., \& Dowling, N. M. (2008). Teacher attrition and retention: A meta-analytic and narrative review of the research. Review of educational research, 78(3), 367-409. doi: https://doi.org/10.3102\%2F0034654308321455

Bradburn, N. M. (1969). The structure of psychological well-being. Chicago: Aldine.

Briner, R., \& Dewberry, C. (2007). Staff well-being is key to school success. London: Worklife Support Ltd/Hamilton House. 
Day, C., \& Qing, G. (2009). Teacher emotions: Well being and effectiveness Advances in teacher emotion research (pp. 15-31): Springer.

Desa, A., Ahmad, A., \& Sharkawi, Z. (2009). Kesejahteraan psikologikal Orang Asli di Pertak dan Gerachi Jaya. JURNAL PSIKOLOGI MALAYSIA, 19-25.

Diener, E. (2009). The Science of Well-Being: The Collected Works of Ed Diener. Netherlands: Springer.

Durr, T., Chang, M.-L., \& Carson, R. L. (2014). Curbing teacher burnout: The transactional factors of teacher efficacy and emotion management Teacher Motivation (pp. 198-213): Routledge.

Emmer, E. T., \& Stough, L. M. (2001). Classroom management: A critical part of educational psychology, with implications for teacher education. Educational Psychologist, 36(2), 103-112. doi: https://doi.org/10.1207/S15326985EP3602_5

Goetzel, R. Z., Ozminkowski, R. J., Sederer, L. I., \& Mark, T. L. (2002). The business case for quality mental health services: why employers should care about the mental health and well-being of their employees. Journal of occupational and environmental medicine, 44(4), 320-330.

Gustems-Carnicer, J., Calderón, C., \& Calderón-Garrido, D. (2019). Stress, coping strategies and academic achievement in teacher education students. European Journal of Teacher Education, 42(3), 375-390. doi: https://doi.org/10.1080/02619768.2019.1576629

Gyeltshen, C., \& Beri, N. (2018). Work Place Happiness: A Tool for Teacher Effectiveness. Indian Journal of Public Health Research \& Development, 9(12).

Harding, S., Morris, R., Gunnell, D., Ford, T., Hollingworth, W., Tilling, K., . . Brockman, R. (2019). Is teachers' mental health and wellbeing associated with students' mental health and wellbeing? Journal of affective disorders, 242, 180-187. doi: https://doi.org/10.1016/j.jad.2018.08.080

Hassan, A., Yusooff, F., \& Alavi, K. (2014). Pengaruh Faktor Kesepaduan (Kefungsian Keluarga) Dan Kemahiran Keibubapaan Terhadap Kesejahteraan Psikologi Dalam Kalangan Ibu Bapa Dan Anak. Sains Humanika, 3(1). doi: https://doi.org/10.11113/sh.v3n1.532

Hong, J. Y. (2012). Why do some beginning teachers leave the school, and others stay? Understanding teacher resilience through psychological lenses. Teachers and Teaching, 18(4), 417-440. doi: https://doi.org/10.1080/13540602.2012.696044

Johnson, B., Down, B., Le Cornu, R., Peters, J., Sullivan, A., Pearce, J., \& Hunter, J. (2015). Promoting early career teacher resilience: $A$ socio-cultural and critical guide to action: Routledge.

Kasim, M. A. B. M., Ismail, S. N., Mohammad, S., \& Ibrahim, H. (2017). Iklim sekolah dan komitmen guru di sekolah agama bantuan kerajaan (SABK) negeri Kelantan. Proceedings of the ICECRS, 1(1).

Lan, H. K., Subramanian, P., Rahmat, N., \& Kar, P. C. (2014). The effects of mindfulness training program on reducing stress and promoting well-being among nurses in critical care units. The Australian Journal of Advanced Nursing, 31(3), 22-31.

Leow, K., Lee, C. E., \& Leow, S. (2020). Job satisfaction and mental wellbeing among high school teachers in Malaysia. JURNAL PSIKOLOGI MALAYSIA, 34(3). doi: http://spaj.ukm.my/ppppm/jpm/article/view/528

Lovewell, K. (2012). Every teacher matters: Ecademy Press.

Marks, N., \& Shah, H. (2004). A well-being manifesto for a flourishing society. Journal of Public Mental Health, 3(4), 9-15. doi: https://doi.org/10.1108/17465729200400023 
Maslach, C., Schaufeli, W. B., \& Leiter, M. P. (2001). Job burnout. Annual review of psychology, 52(1), 397-422.

McGregor, J. A., Camfield, L., \& Woodcock, A. (2009). Needs, wants and goals: Wellbeing, quality of life and public policy. Applied Research in Quality of Life, 4(2), 135-154. doi: https://doi.org/10.1007/s11482-009-9069-7

Michaelson, J., Abdallah, S., Steuer, N., Thompson, S., \& Mar s, N. (2009). National accounts of wellbeing: Bringing real wealth onto the balance sheet. London.

Momtaz, Y. A., Ibrahim, R., Hamid, T. A., \& Yahaya, N. (2011). Sociodemographic predictors of elderly's psychological well-being in Malaysia. Aging \& mental health, 15(4), 437-445. doi: https://doi.org/10.1080/13607863.2010.536141

Myers, D. G., \& Diener, E. (1995). Who is happy? Psychological science, 6(1), 10-19. doi: https://doi.org/10.1111\%2Fj.1467-9280.1995.tb00298.x

Naeemi, S., Tamam, E., Hassan, S. H., \& Bolong, J. (2014). Facebook usage and its association with psychological well-being among Malaysian adolescents. Procedia-Social and Behavioral Sciences, 155, 87-91. doi: https://doi.org/10.1016/j.sbspro.2014.10.261

Ngui, G. K., \& Lay, Y. F. (2019). The Predicting Roles of Self-efficacy and Emotional Intelligence and the Mediating Role of Resilience on Subjective Well-being: A PLS-SEM Approach. Journal of Social Sciences \& Humanities, 1. doi: https://core.ac.uk/download/pdf/219504114.pdf\#page $=15$

Nordin, N. M., \& Talib, M. A. (2009). Kesunyian dan Kesejahteraan Psikologi di Kalangan Pelajar Universiti di Malaysia (Loneliness and psychological well-being among university students in Malaysia). JURNAL PSIKOLOGI MALAYSIA, 23.

Park, M. S.-A., Goto, N., Kennedy, A., Raj, S., Dutson, A., Park, L., \& Sovet, L. (2020). Positive orientation, job satisfaction and psychological well-being of mental health practitioners in Malaysia. Psychology, health \& medicine, 1-11. doi: https://doi.org/10.1080/13548506.2020.1804599

Pavot, W., Diener, E., Oishi, S., \& Tay, L. (2018). The cornerstone of research on subjective wellbeing: Valid assessment methodology. Salt Lake City: DEF Publisher.

Razak, N. A., \& Kutty, F. M. (2021). Daya Tahan, Strategi Daya Tindak Serta Hubungannya Terhadap Tahap Kesejahteraan Psikologi Guru. Malaysian Journal of Social Sciences and Humanities (MJSSH), 6(3), 171-179. doi: https://doi.org/10.47405/mjssh.v6i3.713

Rees, G., Goswami, H., \& Bradshaw, J. (2010). Developing an index of children's subjective well-being in England: Children's Society.

Ryff, C. D. (1989). Happiness is everything, or is it? Explorations on the meaning of psychological well-being. Journal of personality and social psychology, 57(6), 10691081.

Seligman, M. E. (2011). Flourish: A New Understanding of Happiness and Well-being - and how to Achieve Them. New York: Nicholas Brealey.

Shepherd, J., Pickett, K., Dewhirst, S., Byrne, J., Speller, V., Grace, M., . . Roderick, P. (2016). Initial teacher training to promote health and well-being in schools-A systematic review of effectiveness, barriers and facilitators. Health Education Journal, 75(6), 721-735. doi: https://doi.org/10.1177\%2F0017896915614333

Shin, D. C., \& Johnson, D. M. (1978). Avowed happiness as an overall assessment of the quality of life. Social Indicators Research, 5(1), 475-492. doi:

https://doi.org/10.1007/BF00352944 
Simon, L. S., Judge, T. A., \& Halvorsen-Ganepola, M. D. (2010). In good company? A multistudy, multi-level investigation of the effects of coworker relationships on employee well-being. Journal of vocational behavior, 76(3), 534-546. doi: https://doi.org/10.1016/j.jvb.2010.01.006

Statham, J., \& Chase, E. (2010). Childhood wellbeing: A brief overview. Loughborough: Childhood Wellbeing Research Centre.

Stone, A. A., Krueger, A. B., Stiglitz, J., Fitoussi, J., \& Durand, M. (2018). For Good Measure Advancing Research on Well-being Metrics Beyond GDP: Advancing Research on Wellbeing Metrics Beyond GDP: OECD Publishing.

Tahir, N. K. M., Hussein, N., \& Samad, S. (2017). Workload and Subjective Well-Being Among Nurses in Malaysia. Advanced Science Letters, 23(8), 7853-7856. doi: https://doi.org/10.1166/asl.2017.9593

Thartori, V., \& Nordin, M. S. (2019). Structural Equation Modeling and Relationships Between Mental Wellbeing, Resilience and Self-stigma. Research in World Economy, 10(2), 129 135. doi: 10.5430/rwe.v10n2p129

Virtanen, T. E., Vaaland, G. S., \& Ertesvåg, S. K. (2019). Associations between observed patterns of classroom interactions and teacher wellbeing in lower secondary school. Teaching and Teacher Education, 77, 240-252. doi: https://doi.org/10.1016/j.tate.2018.10.013

Wubbels, T., Brekelmans, M., \& Mainhard, T. (2016). Teacher-student relationships and student achievement Handbook of social influences in school contexts (pp. 137-152): Routledge.

Yahya, N., Ishak, H. S., Rahim, N. A., \& Usuldin, H. S. (2020). Kesejahteraan Psikologi dan Keperluan Perkhidmatan Kaunseling dalam Kalangan Guru di Kementerian Pendidikan Malaysia. Jurnal Psikologi dan Kaunseling, 11, 1-32.

Yusoff, S. M., \& Tengku-Ariffin, T. F. (2020). Looking After Teacher Wellbeing: Does Teacher Empowerment Matter? MOJEM: Malaysian Online Journal of Educational Management, 8(4), 43-56. doi: http://jummec.um.edu.my/index.php/MOJEM/article/view/26381

Zakaria, Z., Don, Y., \& Yaakob, M. F. M. (2020). Social Psychology: Differences In The Level Of Teachers'well-Being In Smk And Sabk. International Journal of Management (IJM), 11(7). doi: https://eric.ed.gov/?id=EJ1299271

Zaki, A., \& Halim, A. (2020). Determinants of psychological wellbeing among health care provider in Hospital Tengku Ampuan Rahimah. (Masters), Universiti Utara Malaysia. 